Article

\title{
The Role of Natural Resource Professionals in Addressing Climate Change
}

\author{
Shorna B. Allred ${ }^{1, *}$, Rebecca L. Schneider ${ }^{2}$ and Jordan G. Reeder ${ }^{2}$ \\ 1 Human Dimensions Research Unit, Cornell University, Ithaca, NY 14853, USA \\ 2 Department of Natural Resources, Cornell University, Ithaca, NY 14853, USA; rls11@cornell.edu (R.L.S.); \\ jgr73@cornell.edu (J.G.R.) \\ * Correspondence: srb237@cornell.edu; Tel.: +1-607-255-2149
}

Academic Editor: Yang Zhang

Received: 25 March 2016; Accepted: 3 August 2016; Published: 16 August 2016

\begin{abstract}
Natural resource professionals, ranging from forest managers and educators to floodplain managers, play a critical role in implementing and conducting outreach with regards to climate mitigation and adaptation appropriate to local and regional scales. Natural resource professionals can also pave the way by adopting actions that serve as demonstrations of efforts to mitigate greenhouse gas emissions or adapt natural systems for the future. A web survey of 1488 natural resource professionals across New York State (NYS) was conducted to assess their attitudes toward climate change, views toward climate change mitigation and adaptation priorities, actions taken to address climate change, and barriers faced as they relate to their professional responsibilities. The majority of natural resource professionals believe that climate change is happening, but there was slightly less agreement about human causes of climate change. Most natural resource professionals $(69 \%)$ see evidence of how climate change is impacting natural resources in NYS, but few (17\%) believed that there was sufficient information about how to address climate impacts at the local level. Nearly $60 \%$ of natural resources professionals undertook climate mitigation or adaptation actions in their work. Prominent influencing factors for action were proactive leadership and local impacts. Barriers to taking action on climate change were a lack of human and financial resources, the nature of costs relative to benefits, and lack of perceived threat. As managers and educators responsible for local water, land, and wildlife resources, natural resource professionals witness changes resulting from climate change first-hand. This paper will be useful to decision-makers at state and federal government levels regarding policies, incentives, and guidance that can be created with the goal of promoting a sound natural resource strategy in support of climate change readiness.
\end{abstract}

Keywords: adaptation; mitigation; climate change action barriers; climate action; natural resources

\section{Introduction}

Sustainably managing natural resources in a changing climate is an imperative to both mitigate and adapt to climate change [1,2]. Changes in water resources, forests, fish and wildlife populations, and invasive species will all have critical feedback on agriculture, flooding, and, ultimately, the health of communities in New York State (NYS) and elsewhere [3]. In NYS, there are already observed changes in the overall climate according to the National Climate Assessment [4]. Temperatures increased by $2{ }^{\circ} \mathrm{F}$ from 1895-2011 [4]. Overall rainfall increased by $10 \%$ over the same time period; however, New York and the northeast region saw a greater increase in extreme precipitation events $(70 \%$ from 1958-2010) than did any other region [4]. These trends are predicted to continue through the end of the century [4]. Specific changes will depend strongly on the emissions trend for the globe as a whole, with a $4-10^{\circ} \mathrm{F}$ increase in temperature expected in the northeast under a high emission rate scenario and a $2-6^{\circ} \mathrm{F}$ increase in temperature under lower emission rate scenarios. The frequency, intensity and 
duration of heat waves in NYS are projected to increase, while precipitation changes are less certain [4]. For example, winter and spring precipitation is expected to increase, shifting from snow to rain, with more rain coming as high intensity downpours. During summer and fall months, there will be hotter and longer drought conditions [4].

In NYS, climate change is predicted to bring warmer winter temperatures, increased summer heat and drought, and increased frequency of heavy rainfall events [3]. Potential impacts of these predicted changes include the loss of some forest types such as the spruce/fir forests found at high elevations in the Adirondack region of the state. In addition, ecological communities will shift as tree and wildlife species composition will likely change as the ranges of many plant, animal, and insect species find suitable habitat conditions in areas north of their typical range [3]. Climate change is predicted to expand the areas at risk of flooding by $40 \%-45 \%$ over the next century [5]; in fact, there is evidence that heavy rains and flooding are already affecting municipalities throughout NYS [3,6,7]. As the frequency of high rainfall events increases, so does non-point source pollution caused by runoff from agricultural and urban landscapes into waterways. This runoff can lead to pollution or eutrophication effects, erosion and damage to riparian zones, flood damage to plants, and disturbance to aquatic ecosystems [3]. In NYS, summer water deficits are projected to become more common by mid- to late-century, and the impacts on ecosystems could include reduced primary productivity (vegetation growth) and reduced food and water availability for terrestrial animals [3]. Actions are needed to increase the adaptability of NYS's natural resources to the effects of climate change such as loss and reduced productivity of forests and ecosystem processes, as well as the environmental benefits provided to people (e.g., wildlife, nature, recreation) [1,2]. In addition, as the reality of climate change is gaining acceptance by the general public [8,9], it is important to consider the role that natural resources professionals play in mitigation actions to reduce greenhouse gas emissions and also in adaptation of natural environments for the future [10,11].

It is also worth noting how existing climate change policies in NYS impact natural resources, and where existing policies are insufficient to buffer anticipated impacts. A comprehensive analysis of the potential impacts of climate change on multiple NYS sectors was conducted in 2011 (NYSERDA), which identified multiple ecosystems and specific organisms that would likely be vulnerable to anticipated climate changes [3]. Isolated wetlands were singled out as ecosystems of critical importance across the State both as supporting a disproportionate amount of biological diversity with habitat for rare and endangered species and for providing connectivity to allow dispersal of species across the landscape [3]. These ecosystems, already under threat from development pressures, are particularly vulnerable to increased drought risk associated with climate change. Unlike other states, which responded to the 2001 Supreme Court SWANCC (Solid Waste Agency of Northern Cook County vs. Army Corp of Engineers) decision by creating their own laws to protect important wetland ecosystems, NYS has yet to adopt legislation to protect isolated wetlands. NYS's Governor Andrew Cuomo created the NYS2100 Commission, which produced a report that provided explicit guidance on increasing resilience and climate readiness [12]. The report outlines strategies for water infrastructure-related topics, ranging from wastewater treatment and drinking water supply to dam safety, and even extends to wetlands, stream management and coastal zones. However, the Commission Report does not address the topics of wildlife, invasive species, and forestry, which are critical in a state that is 63\% forested [13]. In 2014, Governor Andrew Cuomo signed a bill into law titled the Community Risk and Resiliency Act (CRRA). The purpose of the bill was to ensure that certain state monies, facility-siting regulations and permits include consideration of the effects of climate risk and extreme-weather events. CRRA requires the NYS Dept. of Environmental Conservation, in consultation with the NYS Dept. of State, to develop guidance on the use of natural resources and natural processes to enhance resiliency. The state agencies responsible for implementing CRRA are currently identifying information needs and organizing staff teams to develop guidance required by CRRA.

Natural resource professionals, defined in this research as those with job responsibilities related to management of or education about natural resources, include natural resource managers 
and practitioners working for state and federal agencies or non-governmental organizations and Cooperative Extension educators working in natural resources program areas. Natural resource professionals play a critical leadership role in identifying and implementing adaptations appropriate at local and regional scales $[1,14]$ and also help support stakeholder decisions and bridge science and society [15]. As a trusted resource in communities, natural resource professionals can help stakeholders by promoting a better understanding of climate change mitigation and adaptation, utilizing climate change communication resources [16] and taking a dialogue-based approach [17]. In fact, stakeholder engagement processes can help to support informed decision-making, as natural resource professionals often help clientele find solutions to problems using applied research and effective outreach $[15,18]$. However, natural resource professionals conducting outreach must be informed about climate change to be effective [19].

This study is aimed at understanding how natural resource professionals are approaching climate change in their profession. Understanding the climate change perspectives and knowledge of natural resource professionals can help identify potential barriers that might prohibit them from implementing relevant climate change mitigation and adaptation actions, and can also inform state climate mitigation and adaptation policy [14]. By conducting a statewide survey of natural resource professionals in NYS, we examined climate change knowledge and attitudes, as well as mitigation and adaptation actions taken by those working in natural resource outreach and management. The survey also measured barriers that natural resource professionals face in taking mitigation and adaptation actions, what factors were most influential in taking action, and what resources, tools, and information would help them to address climate change in their work. Results have implications for the role natural resource professionals play in climate mitigation and adaptation actions and what resources and information resource managers need to address climate change in their work.

\section{Materials and Methods}

A web survey (with up to five reminders) was administered to 1488 natural resource professionals working in outreach, state agencies, federal agencies, land trusts, and non-governmental organizations in NYS in 2009 (in the fields of wildlife, forestry, ecosystems, invasive species, and water resources). Everyone in the sample was directly involved in natural resource management and outreach in some direct capacity. The census of email addresses for the survey was constructed from web sites of the Cornell Cooperative Extension system (county educators and state extension specialists), land trusts operating in NYS (from Land Trust Alliance website), state agencies (e.g., NYS Dept. of Environmental Conservation), federal agencies (e.g., U.S. Fish and Wildlife Service, Natural Resource Conservation Service), and non-governmental organizations (e.g., The Nature Conservancy, Audubon Society). Survey questions covered climate change awareness, knowledge, beliefs, climate change mitigation and adaptation actions, climate change action barriers, and socio-demographic characteristics. Climate change experts (M.S. and Ph.D. level research scientists and outreach professionals) in NYS ( $n=10)$ reviewed the survey instrument before its implementation and provided key input regarding the mitigation and adaptation questions and represented fields of wildlife, forestry, invasive species, and water resources. The authors conducted a telephone survey of non-respondents to the web survey ( $n=100$ telephone survey completions) to determine if there were any significant differences between respondents and non-respondents. The web and telephone surveys were programmed and administered by the Survey Research Institute (SRI) at Cornell University.

\subsection{Study Measures}

Respondents were asked two separate questions, one to indicate climate mitigation actions, and another to indicate climate adaptation actions. For climate change mitigation actions, respondents were asked to indicate what actions they have taken in their agency/organization to mitigate the causes or drivers of climate change and could check all that apply. There were 10 response options: (a) purchase renewable energy; (b) conduct a baseline greenhouse gas emissions inventory and forecast; (c) adopt an 
emissions reduction target for the forecast year; (d) develop a climate action plan to reduce greenhouse gases; (e) adopt the Climate Smart Communities Pledge; (f) make investments to realize energy savings from buildings; (g) make investments to realize energy savings in transportation; (h) make investments to realize energy savings in industrial and waste processes; (i) make investments to protect or increase green and open space; and (j) plant trees.

For the climate adaption question, respondents were asked to indicate what actions they have taken in their agency/organization to adapt to anticipated climate change and could check all that apply. There were 12 response options for climate change adaptation actions: (a) develop a climate action plan; (b) implement a climate action plan; (c) monitor and evaluate a climate action plan; (d) plan for specific climate adaptation at the local level; (e) conduct a climate vulnerability or risk assessment; (f) conduct outreach and education about climate change; (g) work through new or existing partnerships on climate change issues; (h) provide funding for climate research; (i) collect data to monitor climate changes; ( $\mathrm{j}$ ) develop a comprehensive flood mitigation plan or program; (k) plan on a long-term time horizon (10 years or more); and (1) practice adaptive management.

A more specific set of adaptation questions relevant to each area of expertise (e.g., wildlife, water resources) were also asked on the survey (Appendix). Respondents were directed to respond to these questions based on what they self-identified as their area of expertise. Respondents could choose one or more areas of expertise. The survey questions for adaptation actions by area of expertise are provided in the Appendix. Because areas of expertise were not mutually exclusive, statistical comparisons between areas of expertise were not conducted. Except for descriptive data about the specific adaptations, results are presented for the population of natural resource professionals.

Climate change knowledge was self-assessed with the question, "How would you assess your current level of knowledge about potential climate change impacts in New York State?" (Figure 1). The response categories for this question were: I don't know much, I know a little bit, I am moderately well-informed, I am very knowledgable, and I am an expert. The survey questions asked on the questionnaire are provided in the first column of Tables 1-4. Climate change attitudes were assessed with a battery of 18 items and the questions are listed in column 1 of Table 4 .

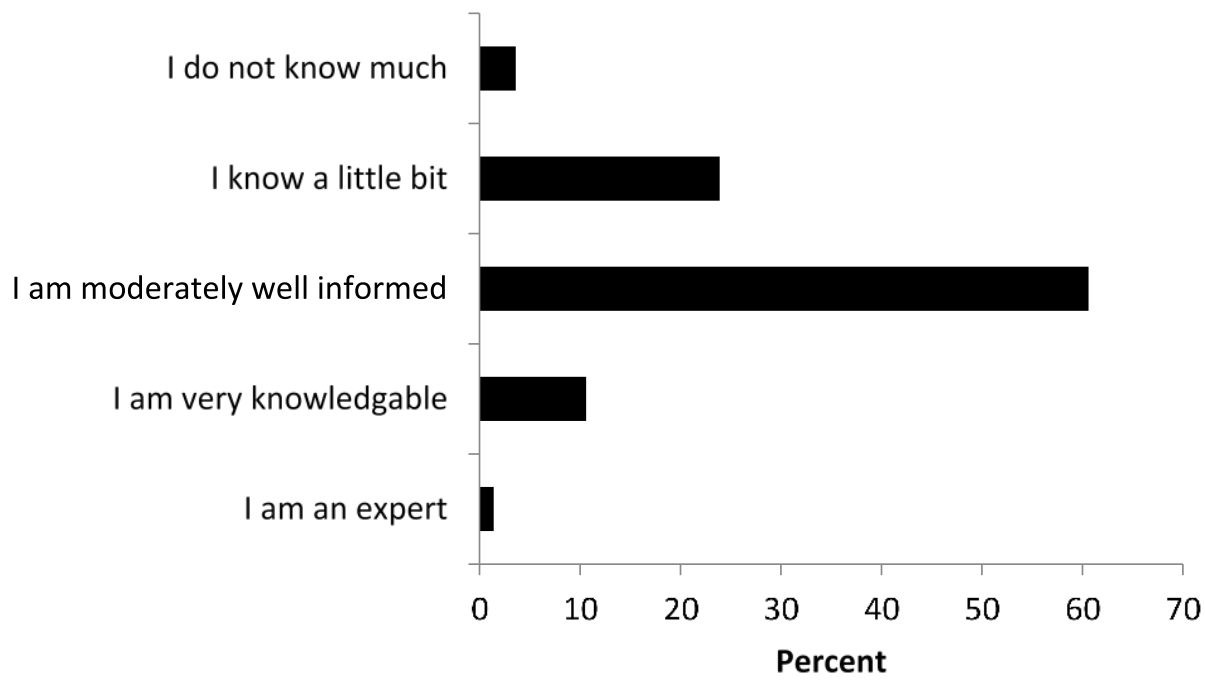

Figure 1. Resopndents self-assessed level of knowledge about climate change. 
Table 1. Factor analysis ${ }^{1}$ results for climate action "Influencing Factors" ${ }^{1}$ including factor loadings, Cronbach's alpha, and scale mean and standard deviation (SD).

\begin{tabular}{|c|c|c|c|c|c|}
\hline & Local Impacts & $\begin{array}{l}\text { Inaction of } \\
\text { Government }\end{array}$ & Fiscal Savings & Pressure to Act & $\begin{array}{l}\text { Proactive } \\
\text { Leadership }\end{array}$ \\
\hline Cronbach's Alpha & $\alpha=0.802$ & $\alpha=0.927$ & $\alpha=0.886$ & $\alpha=0.683$ & $\alpha=0.815$ \\
\hline Scale Statistics & $\begin{array}{c}\text { Mean }=3.451 \\
S D=0.943\end{array}$ & $\begin{array}{c}\text { Mean }=2.913 \\
S D=1.383\end{array}$ & $\begin{array}{c}\text { Mean }=3.130 \\
S D=1.070\end{array}$ & $\begin{array}{c}\text { Mean }=3.130 \\
S D=1.070\end{array}$ & $\begin{array}{c}\text { Mean }=3.868 \\
\mathrm{SD}=0.895\end{array}$ \\
\hline Questionnaire Item & & & Factor Loadings & & \\
\hline Scientific evidence that climate changes are real & 0.799 & 0.139 & -0.077 & 0.159 & 0.152 \\
\hline Perceived threat of climate changes at the local level & 0.614 & 0.307 & 0.181 & 0.069 & 0.263 \\
\hline Impacts of climate change already being felt at the local level & 0.658 & 0.328 & 0.015 & 0.251 & 0.186 \\
\hline Conserving resources and building resilience & 0.583 & 0.054 & 0.133 & -0.080 & 0.476 \\
\hline Concerns about social equity & 0.572 & 0.277 & 0.190 & 0.273 & 0.165 \\
\hline Lack of action at the state level & 0.266 & 0.900 & 0.091 & 0.063 & 0.124 \\
\hline Lack of action at the local level & 0.212 & 0.840 & 0.089 & 0.016 & 0.203 \\
\hline Lack of action at the federal level & 0.313 & 0.816 & 0.140 & 0.112 & 0.133 \\
\hline Short-run fiscal savings (within 5 years or less) & 0.093 & 0.136 & 0.882 & 0.182 & 0.130 \\
\hline Long-term fiscal savings (beyond 5-year time horizon) & 0.075 & 0.155 & 0.871 & 0.188 & 0.161 \\
\hline Responding to requirement or mandate from above & 0.178 & 0.007 & 0.165 & 0.808 & -0.041 \\
\hline Implementing direction from leadership that actions should be taken & 0.249 & 0.018 & 0.154 & 0.738 & 0.222 \\
\hline Constituent pressure to take action & -0.037 & 0.441 & 0.194 & 0.512 & 0.004 \\
\hline Cooperating with other agencies, organizations, etc. & 0.098 & 0.222 & -0.217 & 0.407 & 0.653 \\
\hline Being a responsible leader & 0.181 & 0.001 & 0.273 & 0.027 & 0.809 \\
\hline In order to develop useful partnerships & 0.061 & 0.354 & -0.040 & 0.392 & 0.594 \\
\hline Thinking globally and acting locally & 0.330 & 0.067 & 0.250 & -0.125 & 0.749 \\
\hline Getting a head start on inevitable changes & 0.298 & 0.229 & 0.091 & 0.069 & 0.649 \\
\hline
\end{tabular}

${ }^{1} 70 \%$ variance explained. 
Table 2. Factor analysis results for climate action "Barriers" ${ }^{1}$ including factor loadings, Cronbach's alpha, and scale mean and standard deviation.

\begin{tabular}{|c|c|c|c|c|c|}
\hline & $\begin{array}{l}\text { Lack of Perceived } \\
\text { Impact and } \\
\text { Understanding }\end{array}$ & $\begin{array}{c}\text { Inaction of } \\
\text { Government at All } \\
\text { Levels }\end{array}$ & $\begin{array}{l}\text { Lack of Resources } \\
\text { (Financial and } \\
\text { Human) }\end{array}$ & $\begin{array}{l}\text { Intra-Organization } \\
\text { Issues }\end{array}$ & Financial Costs \\
\hline Cronbach's Alpha & $\alpha=0.899$ & $\alpha=0.915$ & $\alpha=0.765$ & $\alpha=0.558$ & $\alpha=0.778$ \\
\hline Scale Statistics & $\begin{array}{c}\text { Mean }=3.271 \\
S D=1.017\end{array}$ & $\begin{array}{c}\text { Mean }=3.052 \\
S D=1.403\end{array}$ & $\begin{array}{c}\text { Mean }=4.020 \\
S D=1.225\end{array}$ & $\begin{array}{c}\text { Mean }=1.995 \\
S D=1.086\end{array}$ & $\begin{aligned} \text { Mean } & =3.771 \\
S D & =1.089\end{aligned}$ \\
\hline Questionnaire Item & & & Factor Loadings & & \\
\hline Lack of consensus that climate change is real and a current problem & 0.845 & 0.122 & 0.048 & 0.097 & 0.097 \\
\hline Lack of perceived future threat of climate changes at the local level & 0.849 & 0.235 & 0.133 & 0.082 & 0.082 \\
\hline Climate change impacts not yet being felt at the local level & 0.807 & 0.111 & 0.184 & 0.088 & 0.088 \\
\hline Lack of appropriate information/data provided to local government & 0.722 & 0.275 & 0.304 & 0.091 & 0.091 \\
\hline $\begin{array}{l}\text { Level of understanding of climate change and climate change impacts is low } \\
\text { in my organization }\end{array}$ & 0.649 & 0.177 & 0.154 & 0.319 & 0.204 \\
\hline Lack of constituent pressure to take action & 0.556 & 0.493 & 0.027 & -0.113 & -0.113 \\
\hline $\begin{array}{l}\text { Belief that higher government entity should take the lead, not my } \\
\text { organization or local government }\end{array}$ & 0.478 & 0.377 & -0.032 & 0.183 & 0.183 \\
\hline Lack of action at the state level & 0.219 & 0.884 & 0.188 & 0.165 & 0.112 \\
\hline Lack of action at the federal level & 0.199 & 0.864 & 0.171 & 0.173 & 0.106 \\
\hline Lack of action at the local level & 0.272 & 0.791 & 0.223 & 0.074 & 0.158 \\
\hline Lack of funding to develop new programs & 0.141 & 0.255 & 0.811 & 0.811 & 0.286 \\
\hline Lack of staff to take on new initiatives & 0.174 & 0.211 & 0.793 & -0.049 & 0.2096 \\
\hline Conflict with my agency/organization & 0.060 & 0.155 & -0.071 & 0.749 & 0.141 \\
\hline Not perceived by my manager/supervisor as part of my job description & 0.216 & 0.095 & 0.266 & 0.744 & 0.047 \\
\hline High cost of changes to respond and adapt to local impacts of climate change & 0.186 & 0.116 & 0.108 & -0.033 & 0.800 \\
\hline High cost of changes to mitigate greenhouse gas emissions & 0.239 & 0.125 & 0.184 & 0.124 & 0.800 \\
\hline Savings not realized immediately & 0.428 & 0.221 & 0.204 & 0.091 & 0.572 \\
\hline
\end{tabular}

$173 \%$ variance explained. 
Table 3. Factor analysis results for "Resources Needed" ${ }^{1}$ including factor loadings, Cronbach's alpha, and scale mean and standard deviation.

\begin{tabular}{|c|c|c|c|}
\hline & $\begin{array}{l}\text { Decision Tools and } \\
\text { Incentives }\end{array}$ & $\begin{array}{l}\text { Centralized Info } \\
\text { Sharing and } \\
\text { Communication }\end{array}$ & $\begin{array}{l}\text { General and Local } \\
\text { Information }\end{array}$ \\
\hline Cronbach's Alpha & $\alpha=0.914$ & $\alpha=0.889$ & $\alpha=0.654$ \\
\hline Scale statistics & $\begin{array}{c}\text { Mean }=3.965 \\
S D=0.826\end{array}$ & $\begin{array}{c}\text { Mean }=3.903 \\
S D=0.783\end{array}$ & $\begin{array}{c}\text { Mean }=4.087 \\
S D=0.840\end{array}$ \\
\hline Questionnaire Item & & Factor Loadings & \\
\hline Model ordinances that could be adopted by local governments & 0.846 & -0.061 & 0.091 \\
\hline Incorporation of climate change into state regulations & 0.815 & 0.051 & -0.219 \\
\hline Understanding of existing municipal laws or powers that could be used by local government & 0.788 & -0.036 & 0.157 \\
\hline Incentives for adopting specific actions & 0.774 & 0.033 & -0.151 \\
\hline Revised management plans and/or specific detailed planning guidelines reflecting climate change impacts & 0.728 & 0.013 & 0.271 \\
\hline $\mathrm{EPA}^{*}$ regulation of carbon dioxide under the clean air act & 0.700 & 0.131 & -0.307 \\
\hline Funding/grants for mitigation/adaptation efforts & 0.671 & 0.126 & -0.118 \\
\hline Educational resources (fact-sheets, public service announcements, training sessions, webinars, etc.) & 0.615 & -0.047 & 0.398 \\
\hline Information on how to assess vulnerability of resources & 0.570 & 0.270 & 0.138 \\
\hline Information on the economic value of ecosystem services (clean water, flood protection, food, etc.) & 0.518 & 0.204 & 0.146 \\
\hline Institutionalized/centralized data management and delivery program/systems & -0.039 & 0.992 & -0.139 \\
\hline Institutionalized/centralized monitoring systems & 0.018 & 0.883 & -0.190 \\
\hline Additional applied research knowledge about particular effects of climate on resources, habitats, or species & -0.062 & 0.730 & 0.249 \\
\hline A centralized place for information sharing among agencies and organizations within New York State & 0.046 & 0.694 & 0.193 \\
\hline Increased cross-discipline communication and partnerships & 0.127 & 0.629 & 0.163 \\
\hline Additional research on effective adaptations to climate change impacts & 0.226 & 0.584 & 0.157 \\
\hline Citizen volunteers for monitoring changes in climate & 0.306 & 0.500 & -0.143 \\
\hline Further data/information about climate change in general & -0.025 & 0.320 & 0.696 \\
\hline Specific projections of climate change at the local level such as changes in rainfall, temperatures, seal level, etc. & 0.460 & 0.091 & 0.471 \\
\hline
\end{tabular}

${ }^{1} 63 \%$ variance explained. EPA* = United States Environmental Protection Agency. 
Table 4. Respondents' climate change attitudes, sorted by mean score on item.

\begin{tabular}{|c|c|c|c|c|c|c|c|}
\hline & $\begin{array}{l}\text { Strongly Disagree } \\
(\%)\end{array}$ & $\begin{array}{l}\text { Disagree } \\
(\%)\end{array}$ & $\begin{array}{l}\text { Neutral } \\
(\%)\end{array}$ & $\begin{array}{c}\text { Agree } \\
(\%)\end{array}$ & $\underset{(\%)}{\text { Strongly Agree }}$ & Mean & SD \\
\hline a. The science indicates our climate is changing $(n=432)$ & 2.1 & 2.1 & 7.9 & 34.7 & 53.2 & 4.35 & 0.873 \\
\hline $\begin{array}{l}\mathrm{b} \text {. There is sufficient evidence that over the coming decade, climate change } \\
\text { will affect the natural resources with which I work }(n=427)\end{array}$ & 2.3 & 6.6 & 9.1 & 43.6 & 38.4 & 4.09 & 0.971 \\
\hline $\begin{array}{l}\text { c. The effects associated with climate change will impact my immediate } \\
\text { environment }(n=421)\end{array}$ & 2.6 & 5.5 & 13.3 & 56.5 & 22.1 & 3.90 & 0.894 \\
\hline d. Humans are responsible for climate change $(n=425)$ & 6.6 & 4.9 & 16.7 & 41.6 & 30.1 & 3.84 & 1.111 \\
\hline $\begin{array}{l}\text { d. I already see evidence of how climate change is affecting New York's } \\
\text { natural resources }(n=427)\end{array}$ & 2.8 & 9.4 & 18.7 & 43.3 & 25.8 & 3.80 & 1.017 \\
\hline f. My personal actions will have an influence on climate change $(n=417)$ & 6.3 & 9.1 & 16.4 & 49.8 & 18.5 & 3.65 & 1.077 \\
\hline $\begin{array}{l}\text { g. My personal actions will encourage others to take action on climate } \\
\text { change }(n=417)\end{array}$ & 3.4 & 8.9 & 23.5 & 51.8 & 12.5 & 3.61 & 0.932 \\
\hline $\begin{array}{l}\text { h. The effects associated with climate change will impact my personal } \\
\text { finances }(n=387)\end{array}$ & 3.1 & 11.1 & 26.1 & 47.0 & 12.7 & 3.55 & 0.955 \\
\hline $\begin{array}{l}\text { i. The effects associated with climate change will impact my personal } \\
\text { health }(n=384)\end{array}$ & 3.9 & 17.2 & 32.3 & 37.0 & 9.6 & 3.31 & 0.994 \\
\hline $\begin{array}{l}\mathrm{j} \text {. There is sufficient information available on the local effects of climate } \\
\text { change }(n=416)\end{array}$ & 14.7 & 47.8 & 20.9 & 11.5 & 5.0 & 2.44 & 1.017 \\
\hline $\begin{array}{l}\text { k. There is sufficient information available on how to address climate } \\
\text { change impacts at the local level }(n=418)\end{array}$ & 19.1 & 50.2 & 16.7 & 11.5 & 2.4 & 2.28 & 0.979 \\
\hline $\begin{array}{l}\text { 1. I do not currently see a need to address climate change mitigation in the } \\
\text { work that I do }(n=430)\end{array}$ & 25.1 & 43.0 & 17.0 & 11.2 & 3.7 & 2.25 & 1.068 \\
\hline $\begin{array}{l}\mathrm{m} \text {. I do not see a need to address climate change adapatation in the work } \\
\text { that I do }(n=429)\end{array}$ & 26.8 & 50.1 & 11.9 & 8.2 & 3.0 & 2.10 & 0.989 \\
\hline
\end{tabular}




\subsection{Data Analysis}

Scales to measure the constructs of influencing factors, barriers to action, and resources needed were developed via principal components analysis (PCA). Factor analysis is a data reduction procedure and was performed in SPSS Version 21 (Manufacturer, City, US State if applicable, Country). PCA is a type of exploratory factor analysis that is used to determine the underlying dimensions of (survey) data. PCA informs the development of factor scales that represent a conceptual variable and are comprised of multiple questionnaire items. The questionnaire items are assigned to a factor scale based on the strength of their factor loadings [20]. Varimax rotation was used for all PCAs to achieve an orthogonal matrix structure such that each variable loads highly onto only one factor, aiding in the interpretation of the factor [21]. Principal components factor analysis with Varimax rotation was conducted and Cronbach's alpha reliability was computed on three scaled variables: (1) influencing factors for climate change actions (mitigation and adaption); (2) barriers to taking action on mitigation and adaptation; and (3) resources needed to address climate mitigation and adaption. The factor analysis results showing how the variables were constructed are provided in Tables 1-3. Factor loadings range from 0 to 1 , with higher scores indicating a stronger relationship between the questionnaire item and the construct measured by the scale. Factor loadings greater than 0.5 were used to assign questionnaire items to a factor and then the factors were named based on what each one was descriptively and conceptually measuring (e.g., fiscal impacts). Five factors were extracted using PCA for influencing factors: local impacts, inaction of government, fiscal savings, pressure to act, and proactive leadership (Table 1). Five factors were extracted using PCA for barriers to taking action on climate change: lack of perceived impact and understanding, inaction of government at all levels, lack of resources, intra-organization issues, and financial costs (Table 2). PCA extracted three factors for resources needed: decision tools and incentives, centralized information sharing and communication, and general and local information (Table 3). The factor loading, scale mean, standard deviation, and Cronbach's alpha for these three variables are shown in Tables 1-3. Mean scores, standard deviations, and descriptive statistics were also computed for climate change attitudes (Table 4 ). The scales were constructed to measure the underlying dimensions of factors influencing action on climate change as well as barriers to action and resources needed for action.

A telephone survey of non-respondents was conducted to determine any effects of non-response bias. Respondents (web) were compared to non-respondents (telephone) on six socio-demographic variables (gender, race, age, income, education, area of expertise) and did not find statistically significant differences. The differences in the characteristics of respondents and non-respondents were not statistically significant at $p<0.05$ and, therefore, did not warrant weighting of the data.

\section{Results}

A total of 448 natural resource professionals completed the survey (32\% response rate). Survey respondents had a variety of expertise within natural resources: 47\% land management, 37\% water resources, 35\% invasive species, $23 \%$ wildlife, and 11\% fisheries (respondents could select more than one area, so the percentages do not sum to $100 \%$ ). Sixteen-percent of survey respondents were Extension educators $(n=68)$. While many respondents reported only one area of expertise (47\%), 30\% reported two areas, 14\% reported three, and 9\% reported four or more areas of expertise. Respondents were $62 \%$ male and the median age range was $45-54$ years of age; $94 \%$ of respondents were white and 55\% had a graduate or professional degree as their highest level of education (35\% had a B.S. as the highest level). Survey respondents reported natural resource management responsibilities ranging in spatial scale from local, such as working at the parcel (63\%), municipality (17\%), or county (30\%) level to regional scales such as watersheds (67\%). Thirty-percent of respondents had job responsibilities where they were directly responsible for land management, with acreage under their jurisdiction ranging from 10 acres to 500,000 acres. 


\subsection{Climate Change Beliefs and Attitudes}

The majority of respondents believed that they were moderately to very well informed about the issues of climate change (Figure 1). There was a strong consensus among natural resource professionals in NYS that climate change will have impacts on natural resources and on human health and finances (Table 4). Most believed that the science indicates that our climate is changing and agree that both adaptation and mitigation measures are needed (Table 4). Eighty-eight percent of natural resource professionals in this study agree or strongly agree that the science indicates that our climate is changing, with slightly less agreeing or strongly agreeing that humans are responsible for climate change $(72 \%)$. Nearly seventy-percent of respondents (69\%) reported having already observed some effects of climate change in their local environments. However, despite these beliefs, few professionals felt that there was sufficient information about effects of climate change at the local level on how to address climate impacts at the local level (Table 4). Only about 10\% did not see a need to address climate change mitigation $(15 \%)$ or adaptation $(11 \%)$ in their work as a natural resource professional.

\subsection{Actions Taken to Address Climate Change Mitigation and Adaptation}

Fifty-eight percent $(n=226)$ of natural resource professionals responding to this survey indicated that they had undertaken climate mitigation or adaption actions in their work. For mitigation actions, respondents had a mean of 3.0 actions with a minimum of 0 and a maximum of 10 mitigation actions taken. Of the respondents who took action, many listed mitigation actions aimed at reducing carbon emissions in their workplace (50\%); $49 \%$ planted trees to protect and expand green spaces; $39 \%$ invested to reduce transportation energy costs; $25 \%$ purchased renewable energy; $20 \%$ conducted a baseline greenhouse gas inventory; $17 \%$ adopted an emissions reduction target, and $16 \%$ made investments to realize energy savings in industrial processes.

Respondents took a mean of 2.4 adaptation actions (minimum of 0 , maximum of 12 ). The most common activity among those taking climate adaptation action was conducting climate-change related educational and outreach programs with stakeholders $(64 \%)$ and working collaboratively with relevant agencies $(29 \%) ; 14 \%$ conducted vulnerability assessments and $10 \%$ had developed or implemented a climate action plan. Some respondents reported collecting environmental monitoring data $(35 \%)$ and providing funding for climate change research (19\%). Concrete examples of actions taken included resizing culverts for larger stream flows during extreme weather and storm events and conducting an invasive control project.

Respondents rated adaptation actions that they believed were most important to address for their area of expertise (land, water, fish and wildlife, invasives). For fish and wildlife professionals, key adaptations rated highest were maintaining the health and resiliency of key habitats and migration corridors to allow natural adaptation (38\% rated as very important) while monitoring population trends and habitat conditions ( $36 \%$ rated as very important). Also rated as very important adaptations were expanding stream, lake and riparian zone restoration and protection ( $43 \%$ rated as very important) and reducing other anthropogenic stressors such as sprawl, fragmentation, and pollution were most important (50\% rated as very important). For those working with invasives, they stressed providing increased attention on early detection and response (50\% rated as very important) as well as increased regional coordination within NYS and with neighboring states ( $49 \%$ rated as very important). In addition, for the natural resource professionals surveyed who are working with invasives, 39\% thought that an ecosystem-based management approach was very important. For water resources, key climate adaptation strategies were reducing impervious surfaces ( $46 \%$ rated as very important) and creating incentives for protection of water resources through low impact development and better site design ( $44 \%$ rated as very important). Monitoring populations and habitat were common across many areas of expertise ( $40 \%$ invasives, $38 \%$ land, $36 \%$ fish and wildlife, and $26 \%$ water). 


\subsection{Factors Influencing Climate Adaptation and Mitigation Actions}

Prominent factors influencing climate mitigation and adaptation action by respondents were being a responsible and proactive leader, having observed evidence of local impacts from climate change, and seeing evidence of savings or other fiscal benefits (Figure 2). Proactive leadership was comprised of being proactive and getting a head start on addressing changes, being a responsible leader, cooperating with other agencies and developing useful partnerships, and thinking both globally and locally. Local impacts encompassed impacts of or threats of climate change at the local level, scientific evidence that climate changes are real, conserving resources and building resilience, and also concerns about social equity. Thus, experiencing climate change at the local level was related to taking action. Lack of climate change action at state and federal (policy) levels was not a strong motivating factor regarding climate actions taken.
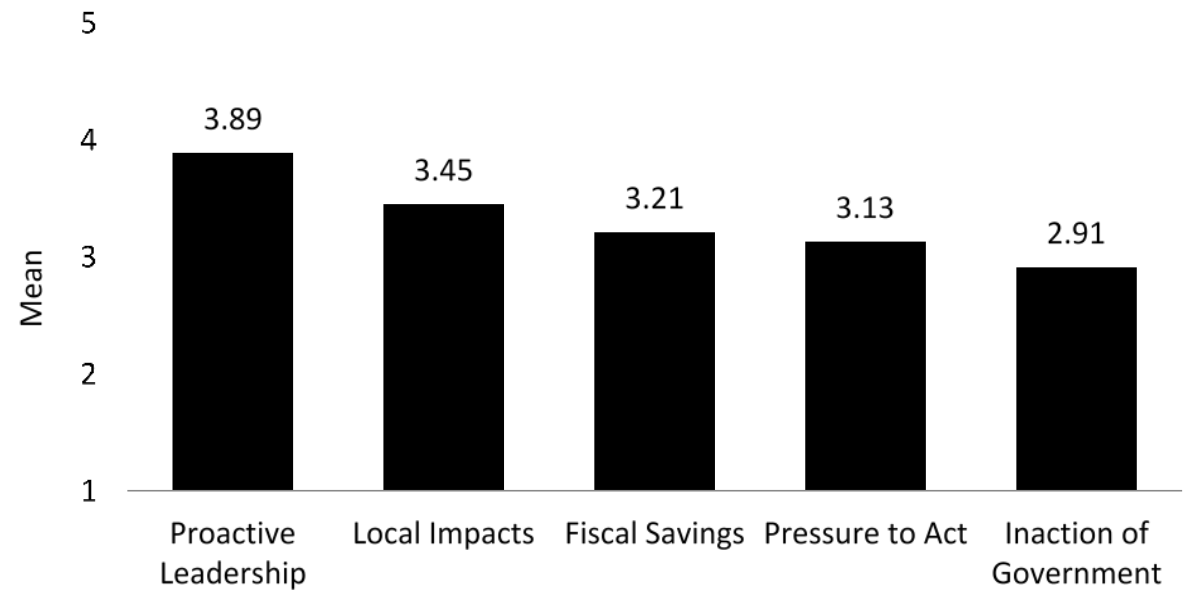

Figure 2. Mean scores for factors influencing natural resource professionals actions regarding climate adaptation and mitigation actions where $1=$ not at all important, $2=$ slightly important, $3=$ somewhat important, 4 = important, 5 = very important.

Conversely, the most significant barriers described by those who had not taken climate mitigation or adaptation actions included lack of financial and human resources, costs relative to benefits, and lack of a perceived threat or understanding of climate change (Figure 3). Lack of resources was about the lack of funding and staff to take on new initiatives. Financial costs were comprised of both mitigation and adaptation costs and also a belief that savings are not realized immediately. This cost may be too high in light of other pressing problems that demand a respondent's attention in their agency or organization. The financial cost barrier was related but distinct from the lack of resources barrier, which was about lack of funding and staff to develop new programs or take on new initiatives, especially with a feeling of being overwhelmed and not knowing where to start. Conflict over climate change within the respondent's agency or organization did not appear to be a significant barrier, nor did inaction of government on climate change.

When asked what resources would be useful in addressing climate chage natural resource impacts, respondents rated all three factor scales highly. Decision tools and incentives had the lowest mean at 3.97, while the centralized information sharing and communication scale had a mean of 3.90 and the local projections and data scale had a mean of 4.10 (where $1=$ not at all useful and $5=$ very useful). Thus, it appears that a range of climate change resources are desired by respondents-particularly those resources and tools that focus on providing local data and information about climate change such as predicted changes in rainfall, temperature, and sea level rise. 


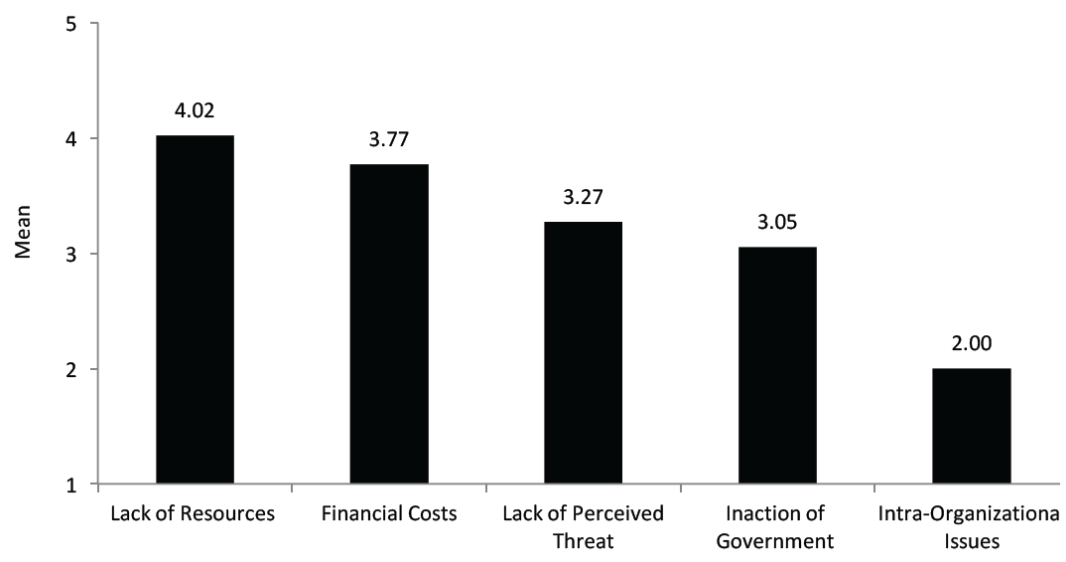

Figure 3. Mean scores for barriers to natural resource professionals taking action on climate adaptation and mitigation actions where $1=$ not a barrier, $2=$ minimal barrier, $3=$ slight barrier, $4=$ moderate barrier, 5 = significant barrier.

\section{Discussion}

Roughly half of the surveyed natural resource professionals throughout NYS stated that they were aware and informed of the phenomenon of climate change. This proactive response and leadership at state and local levels of natural resource professionals is encouraging. More than half of the respondents indicated that they were actively engaged in addressing climate change in their professional capacities. Most of the actions taken by respondents were climate mitigation actions focused on increasing energy efficiency in buildings or transportation systems. Actions such as changing light bulbs or switching to hybrid vehicles all help to reduce greenhouse gas emissions, but, as indicated by the high rating of "fiscal savings" under influencing factors for those taking climate change action, the likely driver was the pressure to reduce expenses associated with rises in fuel costs. In contrast, climate adaptation actions were largely aimed at community outreach and education programs with few conducting vulnerability assessments, implementing specific actions, and monitoring impacts. For example, culvert re-sizing, cited as a climate action by some respondents, is a key strategy to address the increase in storm intensities and associated stream flooding.

For climate change beliefs, nearly all $(88 \%)$ natural resource professionals believe that science indicates that our climate is changing; however, fewer believe humans are responsible for climate change $(72 \%)$. This finding is consistent with studies of the US general public, which show that from 2006-2014, while over half of respondents $(57 \%-85 \%)$ believed that climate change was happening, fewer $(46 \%-83 \%)$ believed that climate change is caused by humans [22,23]. While our findings are consistent with more recent studies of climate change beliefs, it is possible that our study may not reflect more recent fluctuations in climate beliefs.

Less than half of NY's natural resource professionals took no action on climate change, meaning that over half did. Only about one in 10 respondents questioned the reality of climate change, but up to $1 / 5$ of them did not understand the relevance to their work. Not understanding the relevance of climate change to one's professional responsibilities highlights a need for guidance about climate change that is job-specific to natural resource professionals. Most respondents $(69 \%)$ felt there was insufficient information available about the local effects of climate change or how to address those impacts.

The primary barrier to incorporating climate change into work actions included a serious lack of both financial and human resources. A majority reported that the expenses associated with climate change actions outweighed the potential benefits of taking action. The need for addressing climate change during a national economic downturn and accompanying statewide cutbacks is a serious barrier to a proactive approach to climate readiness in NYS. Government officials at every level are often forced to focus on short-term, immediate needs. 
However, in the long-term, a crisis remediation approach may be costlier than being proactive, as evidenced by the average $\$ 50$ million emergency aid that is needed annually to deal with flood damages across NYS [3]. The $\$ 20$ billion remediation price tag associated with 2012 Hurricane Sandy provided convincing evidence that climate adaptation investment now could save money and lives in the near future. In response, NYS Governor Cuomo created the NYS2100 Commission, which produced a report that provided explicit guidance that focuses on increasing resilience and climate readiness [12]. The report outlines strategies for water infrastructure-related topics, ranging from wastewater treatment and drinking water supply to dam safety, and even extends to wetlands, stream management and coastal zones. However, the Commission Report does not address the topics of wildlife, invasive species, and forestry, which are critical gaps in a state with over 18 million acres of forestland [13]. Natural resource professionals have a significant role to play in terms of ensuring that all aspects of resource management are incorporated into adaptation planning.

As managers and educators responsible for local water, land, and wildlife resources, natural resource professionals witness changes resulting from climate change first-hand and make key decisions that will influence the resiliency and sustainability of these resources and what people know about them. Many of these professionals also live and work directly and within their surrounding communities and are often familiar and trusted, and, therefore, can provide leadership and information that may be more likely to be accepted by private citizens. As such, natural resource professionals play a vital role at the local and regional levels. There is a need for leadership in the form of policy mandates, incentives, and guidance that is complementary to local and state level natural resource professionals to promote a sound natural resource strategy in support of climate change readiness.

\section{Conclusions}

The natural resource professionals surveyed provided several consistent recommendations that would help NYS become more climate-ready. Specifically, they emphasized the need for (1) increased monitoring of changes in native and invasive populations, with associated early detection and response programs; and (2) increased protection, restoration, and expansion of habitat, riparian buffers, and migratory corridors to foster natural ecosystem processes that will buffer climate change impacts. Additionally, natural resource professionals desire decision tools and incentives, as well as centralized information sharing and communication. These perspectives can provide a solid framework for a statewide policy focused on natural resources and climate change. Similar conclusions, and, particularly, the key role of increased monitoring, were identified by Mawdsley et al. [24] and by Scott and Lemieux [25] and Baron et al. [26] in their separate analyses of strategies needed to address climate change impacts on protected area management in Canada. However, Scott and Lemieux [25] discussed the need to re-think the role of species considered as alien or invasive, which may be migrating to cooler, northerly locations and, instead of representing a threat requiring a rapid response, may instead be key in replacing those species that can no longer tolerate the higher temperatures and changed climate. Scott and Lemieux [25] also highlighted the importance of recognizing and adapting to the increasingly dynamic nature of formerly "stable" ecosystems within defined park boundaries. Successful flexibility by managers to adapt and respond to climate change impacts was additionally linked to an adaptive governance system, which empowered the managers through financial support and legislation [27].

Acknowledgments: Funding for this project came from a Smith-Lever grant, which made this work possible and informed critical climate outreach activities with natural resource professionals. The authors would like also like to thank all of the natural resource professionals that took the time to respond to the survey and share their perspectives with us.

Author Contributions: Authorship has been limited to those who have made a significant contribution to the conception, design, execution, and interpretation of the study.

Conflicts of Interest: The authors declare no conflict of interest. 


\section{Abbreviations}

The following abbreviations are used in this manuscript:

NYS New York State

\section{Appendix}

\section{Adaptation Questionnaire Items for Each Area of Expertise}

Item Stem: Rate the Following Actions for Their Value as Adaptations to Reduce the Anticipated Impacts of Climate Change in New York. Measurement Scale: Not Important (-5) to Very Important (5)

\section{Land Management Adaptation Actions}

a Maintain the health and resiliency of key habitats and migration corridors (e.g., riparian zones) of sufficient size and distribution to allow natural adaptation to climate change

b Maintain and increase native tree species diversity at the stand and landscape level, including genotypes, ages, and species mixtures to maintain essential forest components to provide a buffer against negative impacts

c Introduce and promote native species that are currently at the northern edge of their range to enhance their proliferations as a hedge against slow natural movement of their range northward. NYSDEC [New York State Dept. of Environmental Conservation] tree nursery should stock seedlings of southern species for public distribution

d Institutionalize long-term monitoring programs, improve data sharing at the regional level, and centralize data management and delivery to land managers and scientists

e Develop and implement comprehensive adaptive management plans, including identification of criteria for prioritization, rapid response plans, education outreach, and training for professionals and citizen science programs

f Establish policies (ex. carbon sequestration markets) that encourage landowners to grow forest plantations on abandoned agricultural land and maintain healthy, growing forests in natural stands

g Collect baseline data

$\mathrm{h}$ Monitor population trends and habitat conditions

Fish and Wildlife Adaptation Actions

a Invasive species management, including rapid response planning, regulation and other means

b Managing the health and resiliency of key habitats and migration corridors of sufficient size and distribution to allow natural adaptation to climate change

c Institutionalize long-term monitoring programs, improve data sharing at the regional level, and centralize data

d Management and delivery to land managers and scientists

e Develop and implement comprehensive adaptive management plans, which might include: identification of criteria for prioritization, rapid response plans, education outreach, and training

f Managing for diversity within and among habitat

$\mathrm{g} \quad$ Expanding wetland conservation efforts

$\mathrm{h}$ Expanding lake, stream and riparian zone restoration and protection

i Establishing flexibility when setting hunting seasons in order to respond changing habits, breeding seasons, abundance, etc., of key game species

j Restoring and improving currently degraded habitats

$\mathrm{k} \quad$ Restoring and improving habitats using plant species on the northern edge of their range 
1 Reducing other anthropogenic stressors such as sprawl, fragmentation, and pollution

m Collecting baseline data

$\mathrm{n} \quad$ Monitoring population trends and habitat conditions

Invasive Species Adaptation Actions

a Increased emphasis on early detection and rapid response

b Developing invasive species risk assessment protocols that incorporate aspects of climate change (e.g., expanding range potential of species)

c Increased vigilance and monitoring of invasion pathways that may be affected by climate change

d Inclusion of climate change in the development of rapid response plans for invasive species

e Enhanced on-the-ground monitoring programs

$\mathrm{f}$ Employing an adaptive management approach

$\mathrm{g}$ More research that examines both invasive species and climate change

$\mathrm{h}$ Increased regional coordination, including regions within NYS as well as neighboring states

i Developing restoration strategies that take climate change into account

j Employing ecosystem-based management

k Collect baseline data

1 Monitor population trends and habitat conditions

Water Resources Adaptation Actions

a Protect or restore forests to reduce runoff and increase rain infiltration

b Repair of remove dams which are at higher risk of failure

c Reform wastewater systems-allow alternatives

d Reform wastewater systems-eliminate CSOs [Combined Sewer Overflow]

e Re-route roadside and agricultural ditch networks so that they do not contribute to stream flooding, droughts and degraded water quality

f Increase monitoring of water quantity (stream flow) and water quality (temperature, contaminants)

g Develop monitoring and rapid response programs for aquatic invasives

$\mathrm{h}$ Develop flood preparedness and emergency response programs at the state, county and town levels in high risk areas

i Implement phased retreat of development from high risk flood areas

j Develop appropriate local ordinances to protect streamside and/or groundwater resources

k Plan infrastructure projects with future climate changes in mind (bridges, train tracks, etc.)

1 Decrease the amount of impervious surfaces. Create incentives for protection of water resources through low impact development, better site design, fewer impervious surfaces, etc.

$\mathrm{m}$ Make room for wetlands to migrate

$\mathrm{n}$ Sequester carbon

o Collect baseline data

p Monitor trends and habitat conditions

\section{References}

1. Alig, R.J. (Ed.) Effects of Climate Change on Natural Resources and Communities: A Compendium of Briefing Papers; Department of Agriculture, Forest Service, Pacific Northwest Research Station: Portland, OR, USA, 2011; p. 169.

2. Swanston, C.; Janowiak, M. Forest Adaptation Resources: Climate Change Tools and Approaches for Land Managers; Department of Agriculture, Forest Service, Northern Research Station: Newtown Square, PA, USA, 2012; p. 121. 
3. Rosenzweig, C.; Solecki, W.; DeGaetano, A.; O'Grady, M.O.; Hassol, S.; Grabhorn, P. Responding to Climate Change in New York State: The ClimAID Integrated Assessment for Effective Climate Change Adaptation; Energy Research and Development Authority (NYSERDA): Albany, NY, USA, 2011; p. 53.

4. Horton, R.; Yohe, G.; Easterling, W.; Kates, R.; Ruth, M.; Sussman, E.; Whelchel, A.; Wolfe, D.; Lipschultz, F. Northeast. Climate Change Impacts in the United States: The Third National Climate Assessment; Melillo, J.M., Richmond, T.C., Yohe, G.W., Eds.; U.S. Global Change Research Program: Washington, DC, USA, 2014.

5. Federal Emergency Management Agency (FEMA). The Impact of Climate Change and Population Growth on the National Flood Insurance Program through 2100. Prepared by Architecture, Engineering, Consulting, Operations, and Maintenance (AECOM) Technology Corporation. Available online: http://www.aecom. com/deployedfiles/Internet/News/Sustainability/FEMA\%20Climate\%20Change\%20Report/ (accessed on 1 June 2013).

6. Gary, G.; Allred, S.B.; LoGiudice, E.; Chatrchyan, A.; Baglia, R.; Mayhew, T.; Wyman, M. Community Adaptation to Flooding in a Changing Climate: Municipal Officials' Actions, Decision-Making, and Barriers. Cornell University, Community and Rural Development Institute (CARDI) and Human Dimensions Research Unit (HDRU) Research and Policy Brief, Issue 57. Available online: http:/ /www.cardi.cornell.edu/cals / devsoc/outreach/cardi/publications/research-and-policy-brief-series.cfm (accessed on 1 December 2013).

7. Gary, G.; Allred, S.B.; LoGiudice, L. An Extension Education Program to Help Local Governments with Flood Adaptation. J. Ext. 2014, 52, 4IAW6.

8. Fraisse, C.W.; Breuer, N.E.; Zierden, D.; Ingram, K.T. From Climate Variability to Climate Change: Challenges and Opportunities to Extension. J. Ext. 2009, 42, 2FEA9.

9. Leiserowitz, A.; Maibach, E.; Roser-Renouf, C.; Feinberg, G.; Howe, P. Global Warming's Six Americas, September 2012; Yale University and George Mason University: New Haven, CT, USA, 2013; p. 45.

10. IPCC. Climate Change 2007: Synthesis Report. Contribution of Working Groups I, II and III to the Fourth Assessment Report of the Intergovernmental Panel on Climate Change; Pachauri, R.K., Reisinger, A., Eds.; IPCC: Geneva, Switzerland, 2007; p. 104.

11. IPCC. Managing the Risks of Extreme Events and Disasters to Advance Climate Change Adaptation; Field, C.B., Barros, V., Stocker, T.F., Qin, D., Dokken, D.J., Ebi, K.L., Mastrandrea, M.D., Mach, K.J., Plattner, G.K., Allen, S.K., et al., Eds.; Cambridge University Press: Cambridge, UK, 2012; p. 582.

12. NYS 2100 Commission. Recommendations to Improve the Strength and Resilience of the Empire State's Infrastructure. Available online: http:/ / www.rockefellerfoundation.org/uploads/files/7c012997-176f-4e80bf9c-b473ae9bbbf3.pdf (accessed on 15 July 2015).

13. Widmann, R.H.; Crawford, S.; Barnett, C.; Butler, J.J.; Domke, G.M.; Griffith, D.M.; Hatfield, M.A.; Kurtz, C.M.; Lister, T.W.; Morin, R.S.; et al. New York's Forests 2007; Forest Service: Newtown Square, PA, USA, 2012; p. 64.

14. Tribbia, J.; Moser, S.C. More than information: What coastal managers need to plan for climate change. Environ. Sci. Policy 2008, 11, 315-328. [CrossRef]

15. Romsdahl, R. Decision support for climate change adaptation planning in the US: Why it needs a coordinated internet-based practitioners' network. Clim. Chang. 2011, 106, 507-536. [CrossRef]

16. Center for Research on Environmental Decisions. The Psychology of Climate Change Communication: A Guide for Scientists, Journalists, Educators, Political Aides, and the Interested Public; Columbia University: New York, NY, USA, 2007.

17. Layman, C.N.; Doll, J.E.; Peters, C.L. Using Stakeholder Needs Assessments and Deliberative Dialogue to Inform Climate Change Outreach. J. Ext. 2013, 51, 3FEA3.

18. Bartels, W.L.; Furman, C.A.; Diehl, D.C.; Royce, F.S.; Dourte, D.R.; Ortiz, B.V.; Zierdan, D.F.; Irani, T.A.; Fraisse, C.W.; Jones, J.W. Warming up to climate change: A participatory approach to engaging with agricultural stakeholders in the Southeast US. Reg. Environ. Chang. 2013, 13, 45-55. [CrossRef]

19. Prokopy, L.S.; Carlton, J.S.; Arbuckle, J.G., Jr.; Haigh, T.; Lemos, M.C.; Mase, A.S.; Babin, N.; Dunn, M.; Andresen, J.; Angel, J.; et al. Extension's role in disseminating information about climate change to agricultural stakeholders in the United States. Clim. Chang. 2015. [CrossRef]

20. Vaske, J.J. Survey Research and Analysis: Applications in Parks, Recreation and Human Dimensions; Venture Publishing: State College, PA, USA, 2008.

21. Hair, J.F.; Black, W.C.; Babin, B.J.; Anderson, R.E. Multivariate Data Analysis, 7th ed.; Pearson: Upper Saddle River, NJ, USA, 2009. 
22. Leiserowitz, A.; Feinberg, G.; Rosenthal, S.; Maibach, E.; Roser-Renouf, C. Climate Change in the American Mind; Center for Climate Change Communication, George Mason Universtiy: Fairfax, VA, USA, 2015.

23. Krosnick, J.A.; MacInnis, B. Does the American public support legislation to reduce greenhouse gas emissions? Daedalus 2013, 142, 26-39. [CrossRef]

24. Mawdsley, J.R.; O'Malley, R.; Ojima, D.S. A review of climate-change adaptation strategies for wildlife management and biodiversity conservation. Conserv. Biol. 2009, 2, 1080-1089. [CrossRef] [PubMed]

25. Scott, D.; Lemieux, C. Climate change and protected area policy and planning in Canada. For. Chron. 2005, 81, 696-703. [CrossRef]

26. Baron, J.S.; Gunderson, L.; Allen, C.D.; Fleishman, E.; McKenzie, D.; Meyerson, L.A.; Oropeza, J.; Stephenson, N. Options for national parks and reserves for adapting to climate change. Environ. Manag. 2009, 44, 1033-1042. [CrossRef] [PubMed]

27. Almstedt, A.; Reed, M.G. Introducing a framework for good and adaptive governance: An application to fire management planning in Canada's boreal forest. For. Chron. 2013, 89, 664-674. [CrossRef]

(C) 2016 by the authors; licensee MDPI, Basel, Switzerland. This article is an open access article distributed under the terms and conditions of the Creative Commons Attribution (CC-BY) license (http://creativecommons.org/licenses/by/4.0/). 